\title{
Can Redistributing Teachers Across Schools Raise Educational Attainment? Evidence from Operation Blackboard in India
}

\author{
Aimee Chin* \\ Department of Economics, University of Houston, 204 McElhinney Hall, Houston, TX 77204, \\ USA
}

\begin{abstract}
I evaluate a reform in India which sought to provide a second teacher to all one-teacher primary schools. The central government paid for 140,000 teachers, which is $8 \%$ of the pre-reform stock of primary-level teachers. I find that less than half of these teachers were sent to the intended place. Additionally, teachers per school did not increase and class size did not decrease. The only effect on school inputs appears to have been the redistribution of teachers from larger schools to smaller schools. This nevertheless generated increases in the primary school completion rate, especially for girls and the poor.
\end{abstract}

JEL Classification: I22, I28, J13, O15

Keywords: schooling, education, policy evaluation

* Tel.: +1-713-743-3761; fax: +1-713-743-3798.

E-mail address: achin@uh.edu (A. Chin). 


\section{Introduction}

An extensive literature demonstrates the central role of education in economic and social development. For example, increasing education raises earnings, reduces fertility and improves child health (World Bank (1997), Shultz (1998)). Recognizing these benefits, developing countries have increased their investment in education, particularly primary education. Despite these efforts, many school-aged children still do not attend school. The World Bank estimates that 125 million school-aged children in developing countries were out of school in 1995 . In India alone, an astounding 30 million, or one-third of the population aged 6 to 10, were out of school. Even when school availability and cost cease to be obstacles, primary school completion is far from universal. School quality seems to be a pivotal factor. In developing countries, where dilapidated school buildings, lack of blackboards and books, large class size, and fewer teachers in a school than grades are not uncommon, school quality may well affect the decision to start and stay in school.

Educational policymakers have responded to the continuing high rate of non-enrollment in primary education by adopting policies to raise school quality. One of the largest and most far-reaching programs to address quality issues has been Operation Blackboard ("OB") in India. Under OB, the central government of India sought to provide all primary schools a teachinglearning equipment packet. This included basic inputs such as blackboards, books, charts and teacher's manuals. Additionally, it sought to provide all primary schools with only one teacher a second teacher. Considering India had a half million primary schools at the program's outset, $29 \%$ of which were one-teacher schools, the resources that had to be mobilized were massive.

It is difficult to assess the overall impact of $\mathrm{OB}$ because various other policies began contemporaneously. However, the teacher component of OB included elements of exogenous 
variation that facilitate evaluation. In particular, intensity of exposure to the teacher component of OB varies by birth cohort (only children attending primary school after 1987 are exposed) and by state of residence (children in states with more one-teacher schools in the pre-program period are more exposed). In this paper I take advantage of these two sources of variation to estimate the effect of the teacher component of OB on school inputs and educational outcomes.

The empirical analysis uses data from a household survey (the National Sample Survey) and a census of school resources (the All-India Educational Survey). The key findings are as follows. First, there was substantial misallocation of OB teachers by state and local governments. Only one-quarter to one-half of the OB teachers were sent to the intended place, i.e., a one-teacher school. Second, the main impact of the program on school inputs was to shift the distribution of primary schools by the number of teachers- there were fewer primary schools with only one teacher, more primary schools with two or more teachers. Average class size did not decrease despite the fact that $\mathrm{OB}$ paid for 140,000 teachers. Third, the teacher component of OB raised primary school completion, especially for girls and the poor. Since the program did not change average class size, the interpretation of this result is that redistributing teachers from larger schools to smaller schools had a positive effect on primary school completion.

This paper is the first rigorous evaluation of any component of OB. ${ }^{1}$ Despite the largescale and locally controversial nature of $\mathrm{OB}$, its effects have heretofore not been convincingly analyzed. A study of the teacher component of OB should be of general interest because India has one-sixth of the world's population and a disproportionate share of its illiterate and poor. Moreover, India's experience should have relevance for educational policies in other countries. Many developing countries share not only the goal of universal primary education, but also the

\footnotetext{
${ }^{1}$ Dyer (2000) provides a rich descriptive analysis of the implementation of Operation Blackboard in the state of Gujarat, but does not attempt to quantify the effects of Operation Blackboard. (This reference is missing in the published version due to author oversight.)
} 
difficult conditions under which it has to be achieved, such as tough budget constraints and tensions between national and local governments. This paper would be an addition to a growing literature on the impact of school inputs on educational and earnings outcomes in a developing country context. ${ }^{2}$ The ordinary least squares coefficient for the school input in a regression of some outcome on the school input does not generally have a causal interpretation because the school input is a choice variable. The OLS coefficient conflates the true impact of the school input and the impact of omitted variables that are correlated with both the school input and the outcome. The variation in school inputs used in this paper arises from a sharp policy shift, and thus could be considered exogenous. Thus, even without the benefit of a randomized experiment, a causal interpretation can be obtained.

The paper is organized as follows. Section 2 provides a background on Operation Blackboard. Section 3 presents the identification strategy. Section 4 describes the data. Section 5 discusses the empirical results. Section 6 concludes.

\section{Background}

\section{A. Operation Blackboard}

Only $67 \%$ of males and $44 \%$ of females aged 15 to 24 had completed a primary education according to the 1991 Census of India. In India, the primary level of schooling generally covers grades one to five. ${ }^{3}$ These grades are offered in primary sections. Primary sections are housed in either schools having fifth grade as the highest grade (these are called primary schools; $85 \%$ of all primary sections are primary schools) or in schools containing higher grades as well. No exam is required to complete a primary education, but there are standards for the curriculum.

\footnotetext{
${ }^{2}$ See, for example, Behrman and Birdsall (1983), Hanushek (1996), Kremer (1996), Angrist and Lavy (1999), Case and Deaton (1999), Duflo (2001), Kremer (2003), Glewwe, Kremer, Moulin and Zitzewitz (2004) and Banerjee, Jacob, Kremer, Lanjouw and Lanjouw (2004).

${ }^{3}$ For a background on primary education in India, see World Bank (1997), Kaur (1985), Tilak (1995) and Probe Team (1999).
} 
Early efforts to expand primary education—building more schools and subsidizing the costs of attending schooling for disadvantaged groups—-had raised educational attainment, but universal primary education remained a distant goal. ${ }^{4}$ Educational policymakers redirected their efforts to improving school quality. In 1987, the Government of India launched the country's first major program to address the problem of school quality. Called Operation Blackboard, the program aimed to provide at least a minimum amount of resources to all public primary schools. Under $\mathrm{OB}$, the Government of India provided a second teacher to all one-teacher primary schools and a teaching-learning equipment packet to all primary schools. ${ }^{5}$

OB was a major policy innovation in several respects. First, it was a huge financial undertaking. Between 1987, the first year of the program, and 1994, when all originally targeted schools had been served, the central government spent 17.2 billion rupees (over $\$ 500$ million U.S. dollars) in 1994 prices on OB. OB was by far the largest centrally sponsored elementary education program, accounting for over half of annual central government spending on elementary education. Second, OB was far-reaching in terms of schools and students affected. By 1994 , OB had made a one-time grant for teaching-learning equipment to 522,909 primary schools (affecting $99 \%$ of the pre-program number of primary schools) and paid for the employment of 143,635 teachers (affecting up to $27 \%$ of primary schools). Third, OB signaled a new commitment by the central government to school quality and to primary education. OB was the centerpiece of the New Policy on Education adopted by Parliament in May 1986. The New

\footnotetext{
${ }^{4}$ The number of primary sections expanded $39 \%$ to 570,010 between 1965 and 1978 alone, such that $93 \%$ of the rural population lived within one kilometer of a primary section in 1978. Incentive schemes were introduced to attract girls, scheduled caste members and scheduled tribe members to school; in 1986, about half the schools offered free textbooks and free uniforms, and a quarter offered free midday meals.

${ }^{5}$ There was in fact a third component to OB: all schools would have at least two classrooms. The central government provided the first two components (teachers and equipment) to existing schools on the condition that the state governments provide the third component to existing schools and all three components to new schools. In theory, this could have led to selective program take-up. In practice, all states chose to participate in $\mathrm{OB}$, and the central government provided the teachers and equipment even when states failed to meet the condition.
} 
Policy on Education heralded greater central government involvement in elementary education, not just through OB. Because of this, it is difficult to assess the overall impact of OB. However, the teacher component of $\mathrm{OB}$ included elements of exogenous variation that facilitate evaluation, and is the concern of the remainder the paper.

B. Teacher Component of Operation Blackboard

The teacher component of $\mathrm{OB}$ accounted for approximately $60 \%$ of cumulative $\mathrm{OB}$ expenditures through $1994 .^{6}$ The policy rule was straightforward: a primary school would be provided a second teacher if it were counted as a one-teacher school by the 1986 All-India Educational Survey ("AIES"). These teachers provided by OB are meant to be permanent additions to the stock of teachers. ${ }^{7}$ The central government strictly adhered to the policy rule. In Table 1, the number of one-teacher schools according to the 1986 AIES (the intended number of OB teacher posts) and the number of teacher posts sanctioned (the number of posts the central government agreed to finance) are nearly identical.

OB resources from the central government are not distributed directly to schools, but instead are mediated through the state and local governments. When a state appoints a teacher to an $\mathrm{OB}$ teacher post, the central government transfers the salary for that teacher to that state. Almost all the teacher posts that the central government agreed to finance were filled by the state, as can be seen from the last column of Table 1 . This does not automatically mean that the states followed the policy rule. The central government did not monitor each state's OB implementation, and it would not have been difficult for state governments to use the OB teachers in unintended ways. First, the OB teachers could have been sent to schools other than

\footnotetext{
${ }^{6}$ The teaching-learning equipment component accounted for the remaining $40 \%$. It included blackboards, books, maps, charts, toys, teacher's manuals and other basic inputs. The full list is provided in Dave and Gupta (1988).

${ }^{7}$ The central government pays the salary of the second teachers only for the initial few years. The state governments must pay the salary for subsequent years.
} 
one-teacher schools. Second, the OB teachers could have merely crowded out teacher hiring out of state budgets. States could have either slowed down their own new teacher hiring, or relabeled existing teachers as OB teachers. Third, states could have hired unqualified individuals to fill the OB posts, possibly using the posts as a way to reward political party loyalists.

How states implemented the program, and what the ultimate impact of the program was on the children's educational outcomes, are open questions. In the next section, I propose a way to identify the effects of the program.

\section{Identification Strategy}

I will estimate the effect of the teacher component of Operation Blackboard by using a difference-in-differences strategy. In particular, the proposed estimate of the average treatment effect is given by $\beta$ in the following equation:

$$
\mathrm{y}_{i j k}=\alpha+\beta\left(\text { Intensity }_{j} \times \text { Post }-O B_{k}\right)+\theta_{j}+\rho_{k}+\pi^{\prime} \mathbf{x}_{i j t}+\varepsilon_{i j k}
$$

for individual $i$ living in state $j$ born in year $k . \mathrm{y}_{i j k}$ is the outcome of interest. Intensity $y_{j}$ is the program intensity in state $j$. OB provided as many teachers to each state as the number of primary schools with only one teacher in that state according to the 1986 All-India Educational Survey. In the 1986 AIES, one-teacher schools constituted as little as 0\% of primary schools in some states, but as much as two-thirds in other states. As a result, there is considerable variation in how many OB teachers a state received relative to the size of its primary school system. For example, Rajasthan received 15,352 OB teacher posts, which is $20 \%$ of the state's primary stage teachers in 1986 and 2.9 teachers per thousand primary-school-aged children. In contrast, its northern neighbor Punjab received only 1,457 OB teacher posts, which is $3 \%$ of the state's primary stage teachers in 1986 and which is 0.7 teachers per thousand children. For the regression analysis, I define state program intensity as the number of one-teacher schools in state 
$j$ per 1,000 children aged 6 to 10 in state $j$ according to the 1986 AIES - this is the intended program intensity. Post-OB $B_{k}$ is a dummy variable for whether the individual was primaryschool-aged after OB was implemented. Taking grades 1 to 5 as the primary school grades, ages 6 to 10 as the corresponding primary school ages and 1988 as the first year that schools could have received OB resources, then the shaded area of Table 2 shows the birth cohorts that have been potentially exposed to OB. Cohorts born 1978 or later (i.e., $k \geq 1978$ ) would have been primary-school-aged for at least one year in the post-OB regime, and therefore potentially exposed to OB. It is important to emphasize that Table 2 reflects only potential exposure by birth cohort since some children start school at a later age, repeat grades, drop out, withdraw temporarily or never enroll. $\theta_{j}$ is the state-specific fixed effect, controlling for the fact that states may be systematically different from each other (most saliently, higher-intensity states may be systematically different from lower-intensity states). $\rho_{k}$ is the birth cohort-specific fixed effect, controlling for the fact that India has been actively trying to expand primary education in the past half century, so there are likely to be secular changes over time. $\mathbf{x}_{i j k}$ is a vector of additional control variables (e.g., sex, social group, parental education, household expenditures).

The interpretation of $\beta$ as the effect of the teacher component of OB rests on the assumption that the coefficients for interactions between birth cohort and state of residence would be zero in the absence of the teacher component of OB. However, it is possible that higher-program-intensity states would have had different trends in educational outcomes from lower-program-intensity states. In my empirical analysis, I will control for differential trends in educational outcomes between higher- and lower-program-intensity states in several ways, taking the general form:

$$
\mathrm{y}_{i j k}=\alpha^{\mathrm{DT}}+\beta^{\mathrm{DT}}\left(\text { Intensity }_{j} \times \text { Post }_{-} \text {OB } B_{k}\right)+\delta \operatorname{Trend}_{j k}+\theta^{\mathrm{DT}}{ }_{j}+\rho^{\mathrm{DT}}{ }_{k}+\pi^{\mathrm{DT}} \mathbf{x}_{i j t}+\varepsilon^{\mathrm{DT}}{ }_{i j k}
$$


with the "DT" superscript denoting detrended estimates. The specific measures of Trend $_{j k}$ that I use are: (1) region (groups of states to be defined below) by sector (rural/urban) dummies interacted with year of birth; (2) state dummies interacted with year of birth; and (3) state program intensity interacted with year of birth. Essentially, the older, untreated cohorts are being used to estimate an interaction effect that has nothing to do with OB. $\beta^{\mathrm{DT}}$ is the effect that is in excess of the secular interaction effect, and can be deemed the effect of the teacher component of $\mathrm{OB}$ to the extent that past trends are continuing apace.

\section{Data}

The regression analysis uses data from two Indian governmental sources. The first source is the All-India Educational Survey. The AIES is a census of schools in India, and provides state level data on the number of one-teacher schools, number of total schools, number of teachers and availability of specific school inputs such as libraries and classrooms. The 1993 AIES is the only survey falling in the post-program period. The 1986 AIES is the survey immediately preceding $\mathrm{OB}$, and in fact the government used it to determine the number of $\mathrm{OB}$ teachers. I use the AIES to define the state program intensity variable and analyze the effects of the teacher component of $\mathrm{OB}$ on school inputs.

The second source is the National Sample Survey ("NSS"). The NSS is a nationally representative household survey that provides data on individuals (e.g., age, sex, educational attainment) and their associated households (e.g., state of residence, social group, education, per capita expenditures). I pool four rounds of the NSS $-42^{\text {nd }}(1986-87), 43^{\text {rd }}(1987-88), 50^{\text {th }}(1993-$ 94) and $52^{\text {nd }}(1995-96)$ - in order to increase the number of observations as well as to observe younger and older cohort at the same ages. I use the NSS data to examine the effect of the teacher component on $\mathrm{OB}$ on primary school completion; an explicit goal of $\mathrm{OB}$ was to raise 
this. ${ }^{8}$ I limit my sample to individuals who are aged 12 to 18 at the time of the survey; the first cutoff is to exclude children who might still be attending primary school, the latter cutoff is to exclude adults (for children, the state of residence (which I have data on) is more likely to be the same as the state they would have attended primary school (which I do not have data on)).

\section{Results}

\section{A. The Allocation of OB Teachers}

To what extent were the teachers appointed under OB actually sent to one-teacher schools? Although I do not have data identifying which teachers were appointed under Operation Blackboard or which schools received them, it is still possible to shed light on the question by examining the extent to which OB teacher appointments reduced the prevalence of one-teacher schools. If the state governments were allocating properly, then the number of oneteacher schools should decrease one-for-one with the number of OB teachers provided.

Figure 1 suggests that there must have been a great deal of misallocation. In 1993, the only post-OB year, there were still 115,000 one-teacher schools, which is $20 \%$ of all primary schools. Although OB paid for 140,000 teachers, the number of one-teacher schools decreased by only 38,000 . In other words, only one out of every four teachers appointed under OB was actually sent to a one-teacher school. This result may be overly pessimistic, since new schools with only one teacher could have been built since 1986. Generously assuming that all new primary schools opened between 1986 and 1993 are one-teacher schools, we still get the result of misallocation of OB teachers: states properly allocated one out of every two OB teachers. ${ }^{9}$

\footnotetext{
${ }^{8}$ The NSS does not have more detailed measures of human capital such as test scores. Although the NSS does ask survey respondents about literacy, it turns out that literacy is not a measure of human capital that is independent of educational attainment. By construction, people who have attended formal education are considered literate, thus it is not possible to distinguish who has received a better-content education using the literacy measure.

${ }^{9}$ States implicitly agreed to provide new schools with at least two teachers by participating in OB, so strictly speaking, measuring the degree of $\mathrm{OB}$ adherence does not require adjusting for the possibility that new schools have only one teacher. This method of taking the number of one-teacher schools in 1993 and subtracting out the number
} 


\section{B. Effect on School Inputs}

The previous subsection found that between one-quarter and one-half of the OB teachers were sent to one-teacher schools. The remaining OB teachers were used in ways the central government had not intended. Given that the state and local governments exercised their discretion in the use of the OB teachers, it is an empirical question to what extent the program actually improved school quality.

In Table 3, I organize school inputs into two categories: ones that could have been affected by the teacher component of OB (Panel A) and ones that should not have been (Panels B and C). For each input, I estimate Equation 1 with state-year data from the All-India Educational Survey. In particular, the data consists of 31 states observed in two separate years (1986, the pre-OB period, and 1993, the post-OB period). If $\beta$ really measures the impact of the teacher component of $\mathrm{OB}$, then it should be zero for the inputs in Panels B and C. A non-zero $\beta$ for an input that is unrelated to OB teachers might be indicative of secular trends that affected all school inputs, or of the causal effects of contemporaneous programs.

The last column of Table 3 displays the estimated $\beta$ for the various inputs. The pattern of the coefficients lends support to the interpretation of the estimated $\beta \mathrm{s}$ as being directly related to the teacher component of OB. None of the difference-in-differences estimates are statistically significant in Panels B and C. They are not significant for inputs provided by major contemporaneous programs targeting primary-school-aged children: the teaching-learning equipment component of $\mathrm{OB}$, the state component of $\mathrm{OB}$, various incentive programs aimed at disadvantaged groups and new primary section openings. Nor are they significant for upper primary (grades 6 to 8 ) and secondary schools (grades 9 to 10). Only primary schools received 
OB teachers, so it makes sense that there are no significant changes at the higher levels.

In contrast, the estimated $\beta$ is significant for some of the inputs that the teacher component of OB could have plausibly affected. Panel A shows that there was a shift away from primary schools with only one teacher towards primary schools with two or more teachers. The percent of schools with one teacher decreased by 4.98 percentage points for each OB teacher provided per 1,000 children. ${ }^{10}$ The percent with two teachers increased by 3.06 percentage points, with three teachers by 0.75 percentage points, etc.

In India, primary sections are housed either in schools containing only the primary grades (these are called primary schools) or in schools containing higher grades as well. Panel A shows that the number of teachers per primary section in primary schools increased-for each $\mathrm{OB}$ teacher provided per 1,000 children, it increased by 0.0869 . However, the number of teachers per primary section excluding primary schools actually decreased by 0.6750 for each OB teacher provided per 1,000 children. Overall, teachers per primary section did not significantly change. These results are consistent with educational administrators shifting around existing resources to come closer in compliance with the policy rule, i.e., reduction in the number of one-teacher schools. Corroborating with this conjecture is that the impact of the teacher component of OB on class size (as measured by the pupil-teacher ratio and the child-teacher ratio) is not statistically significant. If the $\mathrm{OB}$ teachers were net new additions to the stock of teachers that would have existed had the states continued hiring as if $\mathrm{OB}$ never occurred, then the number of teachers per primary section should have increased and class size should have decreased. Instead, teachers per section and class size did not change differentially for higher-intensity states. Perhaps higher-program-intensity states slowed down their own hiring in response to the

\footnotetext{
${ }^{10}$ This same effect can be seen in Figure 1, with the percent of primary schools with one teacher declining more sharply for high-program-intensity states than low-program-intensity states between 1986 and 1993.
} 
teacher component of OB. Or, perhaps they did not alter hiring plans, and would not have had sufficient resources to maintain teachers per section and class size in face of enrollment growth.

OB encouraged the appointment of female teachers such that each school might have one male and one female teacher. The central government did not require the appointment of female teachers, recognizing that it would be difficult to find enough qualified women willing to work in the rural, remote locations that one-teacher schools tend to be located. According to administrative data, $40 \%$ of the teachers appointed under OB were female. This is higher than the female share of primary section teachers in 1986 (30\%), hence we might expect that OB raised the female share of primary section teachers. However, the difference-in-differences estimate for percent female is not significant. As suggested before, the OB teachers may not have been net new additions to the stock of teachers. The state might have merely designated existing female teachers as OB teachers.

Did teacher quality deteriorate as a result of the teacher component of OB? Hiring 140,000 teachers in a span of a few years, which is $8 \%$ of primary section teachers at the outset of $\mathrm{OB}$, could have required hiring increasingly less qualified candidates. ${ }^{11}$ I find that the proportion of primary section teachers who are trained is not affected. Since training is one dimension of teacher quality, this might allay some of the fears that teacher quality deteriorated in the post-OB period.

\section{Effect on Primary School Completion}

The previous subsection suggests that the teacher component of OB did not increase the number of teachers either as scaled by the number of primary sections or as scaled by number of

\footnotetext{
${ }^{11}$ Officials at the Department of Education claim that teacher quality did not deteriorate. There was a large excess supply of teachers of a quality comparable to the existing teaching corps (which is not to say they were all wellqualified teachers) at the outset of $\mathrm{OB}$, and this was drawn upon for the OB appointments. There is excess demand for all government jobs because they are white-collar jobs and provide stable pay for life.
} 
pupils/children. However, it dramatically altered the distribution of teachers. The net effect of the state and local government's discretion in OB policy implementation was that teachers were systematically redirected from larger primary sections (especially schools serving higher than fifth grade) to primary schools with only one or two teachers. Thus, depending on the specific school a child attended, the child may have been exposed to more teachers or fewer teachers. However, unambiguously, more children are attending primary sections with two or more teachers. ${ }^{12}$ What, then, are the implications for individual educational outcomes? I will consider this question in the context of a simple model in which an individual is deciding whether to attend school (alternatively, in which parents decide whether to send their child to school). The child will attend school if the expected benefits of attending exceed the expected costs of attending. Define the costs as the sum of out-of-pocket costs to send the child to school (e.g., tuition, books, uniform, and stationery) and the opportunity cost of the child's time. Benefits depend on a wide variety of things, including the consumption value of being in school and the current and future value of the human capital acquired in school.

The teacher component of OB did not affect expected costs, but potentially affected expected benefits. Teachers control the activity in school, affecting how enjoyable attending school is, and provide instruction, affecting what human capital is developed. If the educational production function were linear in the number of teachers (scaled by schools or students), then the teacher component of OB should have no net impact (since students attending teacherreceiving schools would have better outcomes, and students attending teacher-losing schools would have worse outcomes). However, it is plausible that there are nonlinearities, such that a redistribution of teachers would have a net impact. In India at the outset of OB, 29\% of primary

\footnotetext{
${ }^{12}$ The primary sections that lose a teacher will nonetheless still have multiple teachers (there must be at least one other primary stage teacher to continue to be enumerated as a primary section and at least one higher grade teacher not to be enumerated as a primary school).
} 
schools had only one teacher, and only $15 \%$ had at least as many teachers as grades. In this context, most teachers end up serving the multiple roles of principal, teacher, administrator and babysitter. Teacher absence, which is not infrequent, can close a school. When grades are combined, at any point in time, the teacher will be teaching material that is too advanced or too simple for some students, making on-schedule progress in school difficult. Additional teachers to schools with very few teachers may significantly increase school working days, increase time devoted to teaching-learning activities and decrease multi-grade teaching. On the other hand, additional teachers to schools with more teachers may generate less sizable gains. This means that the increase in expected benefits experienced by students in teacher-receiving schools in the post-OB period may exceed the decrease in expected benefits experienced by students in teacherlosing schools.

As a lower bound on the effect of the teacher component of OB, we can think of the program as redistributing teachers while holding constant the teachers per primary section and class size in each state. ${ }^{13}$ I use the individual-level data from the National Sample Survey to analyze the effect of the teacher component of OB on primary school completion. I perform the analysis separately for boys and girls. It makes sense not to restrict the treatment effect and effects of the control variables to be the same for boys and girls, given the gender bias that has been documented in many parts of India (World Bank (1997), Probe Team (1999)). ${ }^{14}$

Table 4 shows the means of variables for the individuals by sex, cohort and state program intensity. For the purpose of this table, there are two cohort categories (a younger cohort that is

\footnotetext{
${ }^{13}$ This is a lower bound because the OB teachers could have increased teachers per primary section and decreased class size. The correct counterfactual may be that these two measures would have worsened in the absence of OB (because the states cannot afford to hold them constant giving the rapid enrollment growth), not the counterfactual maintained here which is that they would have stayed the same.

${ }^{14}$ It will be evident looking at the coefficients for the control variables in Tables 5 (girls) and 6 (boys) that a pooled regression constraining effects of the independent variables to be the same for boys and girls is a poor fit. More formally, I have tested for structural change between the unconstrained and constrained models.
} 
potentially exposed to OB (born 1978-83) and an older one) and two program intensity

categories (a state is categorized as high if its program intensity exceeded the national mean of 1.6 OB teachers per 1,000 children). Several observations can be made about the data. First, high-intensity states are similar to low-intensity states in terms of income (as measured by monthly per capita expenditure quartiles, with quartile cutoffs determined by the national distribution for the given year), primary school completion and the male-female difference in primary school completion at the outset of OB. Thus, the difference-in-differences strategy should not be confounded by either differential trends that may exist by income, education or gender inequality in education, or the effects of contemporaneous programs allocated on those bases. However, high-intensity states do have more scheduled tribe members (many one-teacher schools are in hilly, sparsely settled areas, which are where the scheduled tribe population tends to reside). Moreover, they are more likely to be located in the northeast, central, south and west regions of India, and less likely to be located in the north and east regions. ${ }^{15}$ Different regions may have different underlying trends, and the estimation should account for this.

Table 5 shows the estimates of the effect of the teacher component of OB on the primary school completion of girls. The first two columns estimate Equation 1, with column 2 controlling for more household variables than column 1. They suggest that girls' primary school completion rate increased by 1.6 percentage points for each OB teacher provided per 1,000 children, and this is significant at the $95 \%$ level of confidence. Although household education and income have large effects on primary school completion, their inclusion does not change the

\footnotetext{
${ }^{15}$ I divided the states and union territories of India into six regions: northeast (Arunachal Pradesh, Assam, Manipur, Meghalaya, Mizoram, Nagaland and Tripura), north (Haryana, Himachal Pradesh, Jammu and Kashmir, Punjab, Uttar Pradesh, Chandigarh and Delhi), east (Bihar, Orissa, Sikkim and West Bengal), central (Madhya Pradesh), south (Andhra Pradesh, Karnataka, Kerala, Tamil Nadu, Andaman and Nicobar Islands, Lakshadweep and Pondicherry) and west (Goa, Daman and Diu, Gujarat, Maharashtra, Rajasthan, and Dadra and Nagar Haveli).
} 
difference-in-differences estimate. ${ }^{16}$

The remaining three columns estimate Equation 2, which allows for a differential trend in primary school completion between higher- and lower-intensity states. In column 3, region by sector-specific trends are used. Specifically, the 31 states are divided into 6 regions (as defined earlier in this subsection), and interactions between these region dummies and year of birth for each the rural sector and urban sector are added. Removing the trend in this way, the differencein-differences estimate is 1.20 percentage points. In column 4 , state-specific trends are used. In particular, interactions between the state dummies and year of birth are added. The differencein-differences estimate is 0.93 percentage points. Finally, in column 5, the trend is allowed to vary by the state program intensity, i.e., the interaction between state program intensity and year of birth is added. The difference-in-differences estimate is 0.91 percentage points. All three detrended estimates are still significant at the $95 \%$ level of confidence.

The estimation results for boys are shown in Table 6 . In column 1, the difference-indifferences estimate is the same magnitude as for girls. The estimate decreases by twenty basis points after controlling for household education and income (column 2). In column 3, controlling for region by sector-specific trends, the difference-in-differences estimate decreases to one percentage point. The difference-in-differences estimate is even lower in magnitude and no longer significant when I control for state-specific trends (column 4) or a trend varying by state program intensity (column 5).

In Table 7, I use the same specifications as in Tables 5 and 6, but allow the treatment

\footnotetext{
${ }^{16}$ Household education is measured as follows. What I refer to as "father's education" in the text is actually the educational attainment of the male adult household member currently aged 33-65 who has attained the most schooling and analogously for "mother's education". I do this because of limitations in the data. The NSS provides information on each household member's relation to the household head. It is difficult to construct complete family interrelationships unless a parent is the household head, or a parent is the only co-resident child of the household head. Due to difficulties with linking the child to his actual parents for the whole sample, I have used proxies for parental education based on maximum education by sex in the household.
} 
effect to vary by the household per capita expenditure quartile of the individual. The teacher component of OB did not impact the richest quartile, but raised the primary school completion of everyone else. For girls, the effect is monotonically decreasing in household income. For example, examining the coefficients in column 4 , the effect per teacher per 1,000 children is 0.69 percentage points for the upper middle quartile, 1.12 percentage points for the lower middle quartile and 2.23 percentage points for the poorest quartile. For boys, the effect is not monotonic, but the poorer half clearly benefits more. Even after detrending, the results for boys in the lower middle quartile remain significant. The primary school completion rate increased about one percentage point per teacher per 1,000 children for boys in the bottom two quartiles.

To summarize Tables 5 to 7, I obtain positive difference-in-differences estimates for all children except those from the richest households. The point estimates are larger for girls than for boys. I interpret these estimates as related to the teacher component of OB. Technically, they may reflect the effect of an additional teacher (provided by the teacher component of OB) or the interaction effect between the extra teacher and the teaching aids (provided by the teachinglearning equipment component of $\mathrm{OB}$ ); these two channels cannot be distinguished empirically because in the post-OB period, all primary schools were to have received the teaching aids. I would argue that it is unlikely that the teaching-learning equipment component of OB plays an important role in the results here. On the one hand, even after OB was reported to be fully implemented, many primary schools still lacked teaching aids that the teaching-learning equipment component of $\mathrm{OB}$ was supposed to have provided. ${ }^{17}$ According to the AIES, only $27 \%$ of primary schools had a soccer ball in $1993,29 \%$ had a dictionary and $48 \%$ had a library (the latter two statistics exclude Uttar Pradesh due to missing data). Also, the Probe Team

\footnotetext{
${ }^{17}$ Selective implementation of the teaching-learning equipment component of OB should not be a problem for the difference-in-differences strategy used in the paper. Table 3, Panel B showed that the treatment variable is not associated with the availability of items in the OB teaching-learning equipment packet.
} 
(1999) visited thousands of village primary schools in five states in India in 1996 and found that only $56 \%$ had some functional teaching aids. On the other hand, even when schools did have functional teaching aids, the aids were often not used. It was not uncommon for the aids to be locked away by the teacher, who wanted to avoid blame for loss or damage. The Probe Team reports: "Only half of the teachers who had functional teaching aids reported using them during the seven days preceding the survey, and even that is likely to involve some over-reporting" (p. 43). As a result, the number of schools whose activities were changed by the teaching-learning equipment component of OB could be few.

How can the larger benefit for girls be interpreted in the context of the simple model of the school attendance decision? The program must have raised the expected benefits more for girls than for boys. One channel for this is that teachers pay more attention to boys (because teachers favor boys, or boys demand more immediate attention). This teacher behavior has been observed in both developed and developing countries (see, for example, Sadker and Sadker (1994) for the U.S. and Probe Team (1999) for India). When there is only one teacher, girls may receive little attention. With an additional teacher, girls may finally receive some attention.

A second channel is that parents are more concerned about the physical safety of daughters than of sons. The Probe Team (1999) writes based on an extensive field study of primary schooling in rural India: "Girls are also the victims of parental anxiety. According to parents, daughters study only as far as school facilities within the village permit, because it is not safe to send a girl out of the village to study" (p. 34). Also: "Parents do not want their children to idle around. Nor do they want their daughters to go to schools where teachers are absent, and where they have to relieve themselves in the open for lack of toilets" (p. 49). When all teachers are absent, school is closed and there is no supervision for the children who show up. There is a 
greater chance school will be closed when there is only one teacher, so parents are less likely to allow their daughters to attend a one-teacher school.

A third channel is that parents prefer a female teacher for their daughters, or girls themselves prefer a female teacher. This could be due to religious reasons, or because female teachers serve as role models for girls. OB explicitly encouraged the appointment of female teachers such that each school might have one male and one female teacher. Although the difference-in-differences estimate for female share of primary section teachers was zero (Table 3 ), it is possible that female teachers were redistributed in the same manner as all OB teachers. That is, educational administrators could have shifted female teachers to smaller schools. A greater percent of primary sections would have at least one female teacher.

It is interesting to note that the larger effect of the teacher component of $\mathrm{OB}$ on girls is consistent with the results of a randomized evaluation of a program that provided a second teacher to non-formal education centers in Rajasthan, India. Banerjee et al. (2004) find the program significantly increased the attendance of girls but had no effect on the attendance of boys. ${ }^{18}$ The increase in girls' attendance might be attributed to the higher number of teachers per center (on average, there were 1.16 teachers at a two-teacher center, compared to 0.61 at a oneteacher center), the higher probability that the center is open (two-teacher centers were open $76 \%$ of the time, compared to $61 \%$ for one-teacher centers), or the higher probability of having at least one female teacher in the center (63\% of new teachers were female, compared to less than $20 \%$ of old teachers). They also provide evidence that the first female teacher to a school raises girls' attendance, but a second female teacher does not. These results in Banerjee et al. lend support to

\footnotetext{
${ }^{18}$ However, they do not find an effect on test scores, either for boys or girls. The test may measure a different kind of human capital than what is measured by the primary school completion outcome used here. The latter reflects attendance for a certain number of years and some accumulation of human capital pursuant to the primary curriculum. That there is much grade repetition suggests that there are some standards for grade promotion.
} 
the three channels discussed above for why girls would gain more from the teacher component of OB.

Besides girls, the poor disproportionately benefited from the program. There are a couple of ways for the simple model to explain this. First, suppose within a state the rich and poor are geographically segmented and attend separate schools. One-teacher schools tend to be located in areas that are remote and less desirable to live in. Additionally, richer areas have the supplemental financial resources and the political connections to get the school inputs (including teachers) that they want. As such, OB teachers were probably more likely to be sent to schools serving the poor rather than schools serving the rich. Thus, the expected benefits of attending school increased more for the poor. Alternatively, suppose the rich and the poor lived side by side and were served by the same schools. Initially the expected benefit of attending school is lower than the expected cost unless school attendance is supplemented by private tutoring. Only those who can afford tutoring attend school. The teacher component of OB raises the expected benefit for everyone, bringing the expected benefit above the expected cost for some children. It is now worthwhile for these children to attend school even without a tutor. The program increases the attendance of the poor more since before the program the rich with tutors were already attending.

\section{Conclusions}

Operation Blackboard was an ambitious program to improve and expand primary education in India. In this paper, I evaluated the teacher component of OB, which accounted for the majority of central government OB expenditures. First, there was substantial misallocation of OB teachers by state and local governments. Only one quarter to one half OB teachers were sent to one-teacher primary schools. There is little ambiguity in the policy rule, and the central 
government might have met its policy objectives better had it monitored state implementation more closely, e.g., asking for the names of the $\mathrm{OB}$ appointees (and check whether they are existing teachers) and the specific schools they were sent (are they one-teacher schools?). Second, the main impact of the program on school inputs was to shift the distribution of primary schools by the number of teachers-there were fewer primary schools with only one teacher, more primary schools with two or more teachers. The teacher component of OB was effectively an expensive way to redistribute teachers across schools within a state (it cost $\$ 300$ million from 1987-94 in 1994 U.S. dollars). Despite being enacted ineffectively, the teacher component of OB increased primary school completion rate by up to four percentage points for girls and up to two percentage points for boys based on the average program intensity of 1.6 and detrended estimates. These effects are economically meaningful, as the mean primary school completion rate was only $46 \%$ for girls and $64 \%$ for boys for the pre-OB cohorts in the sample. The teacher component of OB did not raise primary school completion for children from the richest households, and raised it the most for children from the poorer half of the population.

These findings suggest that equalizing resources in public schools may be a way to raise educational attainment and close the gender and income gaps in educational attainment. Presumably there are cheaper ways to redistribute than through an expensive program like OB. In theory, attaining fewer one-teacher schools could involve just moving existing teachers around, and cost nothing. In practice, there could be costs. On the one hand, teachers may need to be compensated for moving to new, more remote locations. On the other hand, it may be politically infeasible to take teachers away from resource-rich schools. Possibly, OB managed to effect a redistribution because teacher-losing schools received other extra resources at the same time. A more feasible alternative might be to reserve most of the future hiring slots for smaller 
schools (i.e., redistribute over a longer time horizon). Another might be to consolidate oneteacher schools to form larger schools. Since one-teacher schools tend to be in remote locations, to maintain universal access to primary education, a subsidized transportation scheme would have to be introduced.

It will be interesting to follow the cohorts affected by the teacher component of Operation Blackboard into adulthood. What are the longer-run effects, such as the effect on eventual employment, earnings, educational attainment and fertility behavior? 


\section{Acknowledgements}

I thank Josh Angrist, Abhijit Banerjee, Esther Duflo, Michael Kremer, the editor Mark

Rosenzweig, an anonymous referee and participants in the Fall 2000 MIT Labor/Public

Economics Workshop for valuable comments and suggestions. Also, I thank officials at the

Government of India Department of Education, National Council of Educational Research and

Training, National Institute of Educational Planning and Administration and National Sample

Survey Organization in New Delhi for data provision and helpful discussion. Financial support

from the MIT Shultz Fund and MacArthur Foundation Research Network on Inequality and

Economic Performance is gratefully acknowledged. I am responsible for any errors that may

remain.

\section{References}

Angrist, J.D., Lavy, V., 1999. Using Maimonides' rule to estimate the effects of class size on scholastic achievement. Quarterly Journal of Economics 114: 533-575.

Banerjee, A., Jacob, S., Kremer, M., Lanjouw, J., Lanjouw, P., 2004. How much would universal primary education cost? Mimeo, Harvard University Department of Economics, Cambridge, MA.

Case, A., Deaton, A., 1999. School inputs and educational outcomes in South Africa. Quarterly Journal of Economics 114: 1047-1084.

Dave, P.N., Gupta, D., 1988. Operation Blackboard: Essential Facilities at the Primary Stage, Norms and Specifications. NCERT, New Delhi.

Duflo, E., 2001. Schooling and labor market consequences of school construction in Indonesia: evidence from an unusual policy experiment. American Economic Review 91: 795-813.

Dyer, Caroline, 2000. Operation Blackboard: Policy Implementation in Indian Elementary Education. Symposium Books, Oxford. (This reference is missing in the published version due to author oversight.)

Glewwe, P., Kremer, M., Moulin, S., Zitzewitz, E., 2004. Retrospective vs. prospective analyses of school inputs: the case of flip charts in Kenya. Journal of Development Economics 74: 251-268.

Government of India Department of Education, various years. Selected Educational Statistics. Ministry of Human Resource Development, Department of Education, Planning, Monitoring and Statistics Division, New Delhi. 
Hanushek, E.A., 1996. Interpreting recent research on schooling in developing countries. World Bank Research Observer 10: 227-246.

Kaur, K., 1985. Education in India (1781-1985): Policies, Planning and Implementation. Centre for Research in Rural and Industrial Development, Chandigarh.

Kremer, M.R., 1996. Research on schooling: what we know and what we don't: a comment. World Bank Research Observer 10: 247-524.

Kremer, M., 2003. Randomized evaluations of educational programs in developing countries: some lessons. American Economic Review Paper and Proceedings 93: 102-106.

National Council of Educational Research and Training (NCERT), various years. All-India Educational Survey. NCERT: New Delhi.

National Sample Survey Organization (NSSO), various years. National Sample Survey. Ministry of Planning, Department of Statistics, New Delhi.

Probe Team, 1999. Public Report on Basic Education in India. Oxford University, New Delhi.

Sadker, M., Sadker, S., 1995. Failing at Fairness: How America's Schools Cheat Girls. Simon and Schuster, New York.

Shultz, T.P., 1998. Education investments and returns, in: Chenery, H., Srinivasan, T.N. (Eds.), Handbook of Development Economics, Vol. 1. North Holland, Amsterdam, pp. 543-630.

Tilak, J.B.G., 1995. Elementary education in India in the 1990s: problems and perspectives. Margin 387-407.

World Bank, 1997. Primary Education in India. World Bank, Washington, DC. 


\section{Figure 1. Prevalence of One-Teacher Primary Schools}

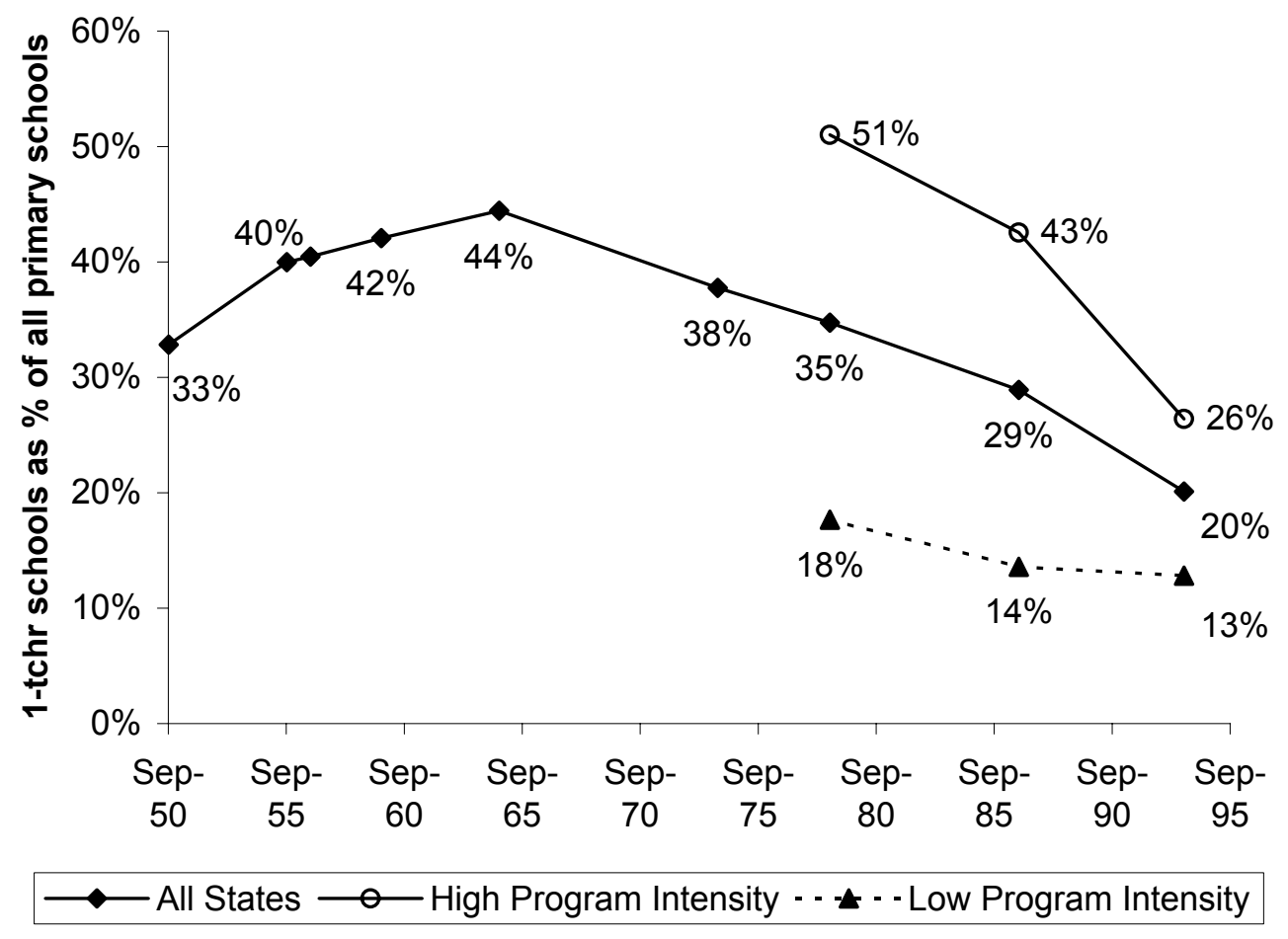

Notes: Pre-1965 data from Kaur (1985), 1965 and after from various All-India Educational Surveys. The statistics are weighted by the number of primary schools to obtain population means. States are classified as "high program intensity" if they received more than the mean number of OB teachers per 1000 children (1.6), and "low program intensity" otherwise. State program intensity is shown in Table 1. 
Table 1. Operation Blackboard Intensity by State

\begin{tabular}{|c|c|c|c|c|c|c|}
\hline \multirow[b]{3}{*}{$\begin{array}{l}\text { state/union territory } \\
\text { name }\end{array}$} & \multicolumn{4}{|c|}{ Pre-OB: 1986} & \multirow{2}{*}{\multicolumn{2}{|c|}{$\begin{array}{c}\text { OB Implementation, } \\
1987-94\end{array}$}} \\
\hline & \multirow{2}{*}{$\begin{array}{c}\text { one-teacher } \\
\text { primary } \\
\text { schools } \\
\end{array}$} & \multirow{2}{*}{$\begin{array}{c}\text { 1-tchr sch as \% } \\
\text { of all primary } \\
\text { schools } \\
\end{array}$} & \multirow{2}{*}{$\begin{array}{l}\text { 1-tchr sch as } \% \\
\text { of all primary } \\
\text { teachers } \\
\end{array}$} & \multirow{2}{*}{$\begin{array}{c}1 \text {-tchr sch per } \\
1000 \text { children } \\
\text { aged } 6 \text { to } 10 \\
\end{array}$} & & \\
\hline & & & & & $\begin{array}{c}\text { teachers } \\
\text { sanctioned }\end{array}$ & $\begin{array}{c}\text { teachers } \\
\text { appointed }\end{array}$ \\
\hline Andhra Pradesh & 18,032 & $41 \%$ & $16 \%$ & 2.7 & 18,032 & 18,032 \\
\hline Arunachal Pradesh & 526 & $55 \%$ & $20 \%$ & 5.7 & 526 & 526 \\
\hline Assam & 8,903 & $34 \%$ & $14 \%$ & 3.1 & 8,903 & 8,903 \\
\hline Bihar & 13,303 & $26 \%$ & $10 \%$ & 1.4 & 13,303 & 13,303 \\
\hline Goa, Daman and Diu & 170 & $17 \%$ & $4 \%$ & 1.4 & 167 & 166 \\
\hline Gujarat & 4,784 & $38 \%$ & $7 \%$ & 1.0 & 2,374 & 2,374 \\
\hline Haryana & 382 & $8 \%$ & $1 \%$ & 0.2 & 382 & 345 \\
\hline Himachal Pradesh & 1,951 & $28 \%$ & $11 \%$ & 3.0 & 1,951 & 1,951 \\
\hline Jammu and Kashmir & 4,380 & $59 \%$ & $22 \%$ & 5.5 & 4,380 & 4,380 \\
\hline Karnataka & 14,350 & $62 \%$ & $16 \%$ & 3.1 & 14,350 & 13,887 \\
\hline Kerala & 19 & $0 \%$ & $0 \%$ & 0.0 & 0 & 0 \\
\hline Madhya Pradesh & 22,163 & $35 \%$ & $12 \%$ & 3.1 & 22,163 & 19,574 \\
\hline Maharashtra & 16,660 & $44 \%$ & $9 \%$ & 2.1 & 15,604 & 15,604 \\
\hline Manipur & 510 & $18 \%$ & $5 \%$ & 2.7 & 338 & 60 \\
\hline Meghalaya & 1,969 & $53 \%$ & $29 \%$ & 8.5 & 1,969 & 1,969 \\
\hline Mizoram & 119 & $12 \%$ & $4 \%$ & 1.4 & 119 & 119 \\
\hline Nagaland & 42 & $4 \%$ & $1 \%$ & 0.4 & 42 & 25 \\
\hline Orissa & 14,112 & $41 \%$ & $17 \%$ & 4.1 & 14,112 & 14,112 \\
\hline Punjab & 1,457 & $11 \%$ & $3 \%$ & 0.7 & 1,457 & 871 \\
\hline Rajasthan & 15,352 & $55 \%$ & $20 \%$ & 2.9 & 15,352 & 15,352 \\
\hline Sikkim & 21 & $4 \%$ & $1 \%$ & 0.4 & 45 & 45 \\
\hline Tamil Nadu & 2,724 & $9 \%$ & $2 \%$ & 0.5 & 2,724 & 2,724 \\
\hline Tripura & 145 & $8 \%$ & $1 \%$ & 0.5 & 145 & 145 \\
\hline Uttar Pradesh & 8,891 & $12 \%$ & $3 \%$ & 0.6 & 8,891 & 8,891 \\
\hline West Bengal & 1,679 & $3 \%$ & $1 \%$ & 0.2 & 1,679 & 143 \\
\hline A \& N Islands & 41 & $23 \%$ & $4 \%$ & 1.1 & 7 & 7 \\
\hline Chandigarh & 1 & $2 \%$ & $0 \%$ & 0.0 & 0 & 0 \\
\hline Dadra and Nagar Haveli & 83 & $67 \%$ & $24 \%$ & 7.3 & 80 & 80 \\
\hline Delhi & 3 & $0 \%$ & $0 \%$ & 0.0 & 0 & 0 \\
\hline Lakshadweep & 1 & $6 \%$ & $0 \%$ & 0.2 & 0 & 0 \\
\hline Pondicherry & 75 & $22 \%$ & $3 \%$ & 1.0 & 51 & 47 \\
\hline All-India & 152,848 & $29 \%$ & $\overline{8 \%}$ & 1.6 & 149,146 & 143,635 \\
\hline
\end{tabular}

Sources: Pre-OB data from the 1986 All-India Educational Survey. OB implementation data from the Department of Education.

The boldfaced column contains the state program intensity measure used in this paper. 
Table 2. Potential Exposure to OB by Year of Birth

\begin{tabular}{c|ccccc|c}
\hline & \multicolumn{7}{c|}{$\begin{array}{c}\text { Primary School } \\
\text { year of } \\
\text { birth }\end{array}$} & $\begin{array}{c}\text { Grade 1 } \\
\text { Age 6 }\end{array}$ & $\begin{array}{c}\text { Grade 2 } \\
\text { Age 7 }\end{array}$ & $\begin{array}{c}\text { Grade 3 } \\
\text { Age 8 }\end{array}$ & $\begin{array}{c}\text { Grade 4 } \\
\text { Age 9 }\end{array}$ & $\begin{array}{c}\text { Grade 5 } \\
\text { Age 10 }\end{array}$ & \\
1968 & 1974 & 1975 & 1976 & 1977 & 1978 & \\
1969 & 1975 & 1976 & 1977 & 1978 & 1979 & \\
1970 & 1976 & 1977 & 1978 & 1979 & 1980 & \\
1971 & 1977 & 1978 & 1979 & 1980 & 1981 & \multirow{2}{*}{ no } \\
1972 & 1978 & 1979 & 1980 & 1981 & 1982 & exposure to OB \\
1973 & 1979 & 1980 & 1981 & 1982 & 1983 & \\
1974 & 1980 & 1981 & 1982 & 1983 & 1984 & \\
1975 & 1981 & 1982 & 1983 & 1984 & 1985 & \\
1976 & 1982 & 1983 & 1984 & 1985 & 1986 & \\
1977 & 1983 & 1984 & 1985 & 1986 & 1987 & \\
\hline \hline $\mathbf{1 9 7 8}$ & 1984 & 1985 & 1986 & 1987 & 1988 & partial \\
$\mathbf{1 9 7 9}$ & 1985 & 1986 & 1987 & 1988 & 1989 & exposure to OB \\
$\mathbf{1 9 8 0}$ & 1986 & 1987 & 1988 & 1989 & 1990 & \\
$\mathbf{1 9 8 1}$ & 1987 & 1988 & 1989 & 1990 & 1991 & full \\
\hline \hline $\mathbf{1 9 8 2}$ & 1988 & 1989 & 1990 & 1991 & 1992 & exposure to OB \\
$\mathbf{1 9 8 3}$ & 1989 & 1990 & 1991 & 1992 & 1993 & \\
\hline \hline
\end{tabular}

Notes: Each cell contains the year an individual with the year of birth specified in the first column would have attended the grade specified in the top row. Shaded area is where individuals were potentially exposed to OB. Potential exposure is determined by assuming that children are "on-schedule" with regard to their schooling, ie, start grade 1 at age 6 and complete primary school in five years. Also, it assumes that 1988 is the first year OB would have reached schools. Although fiscal year 1987 is the first year the central government allocated and disbursed funds for $\mathrm{OB}$, schools probably did not first receive $\mathrm{OB}$ resouces until the following year (school year 1988 would be July 1, 1988 to June 30, 1989). 
Table 3. Effect on School Inputs

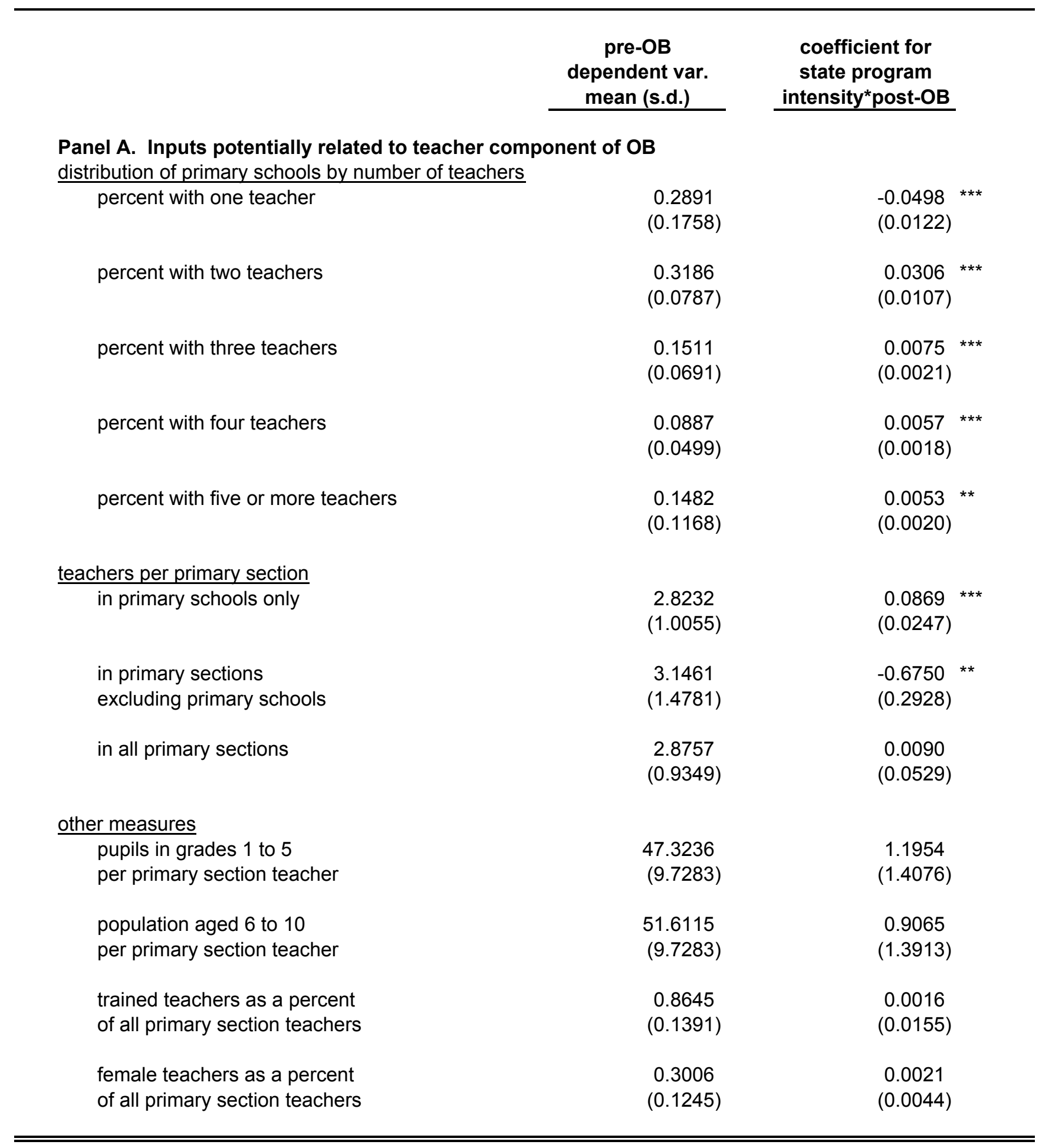

Notes: Table continues on next page. See notes at the end of the table. 


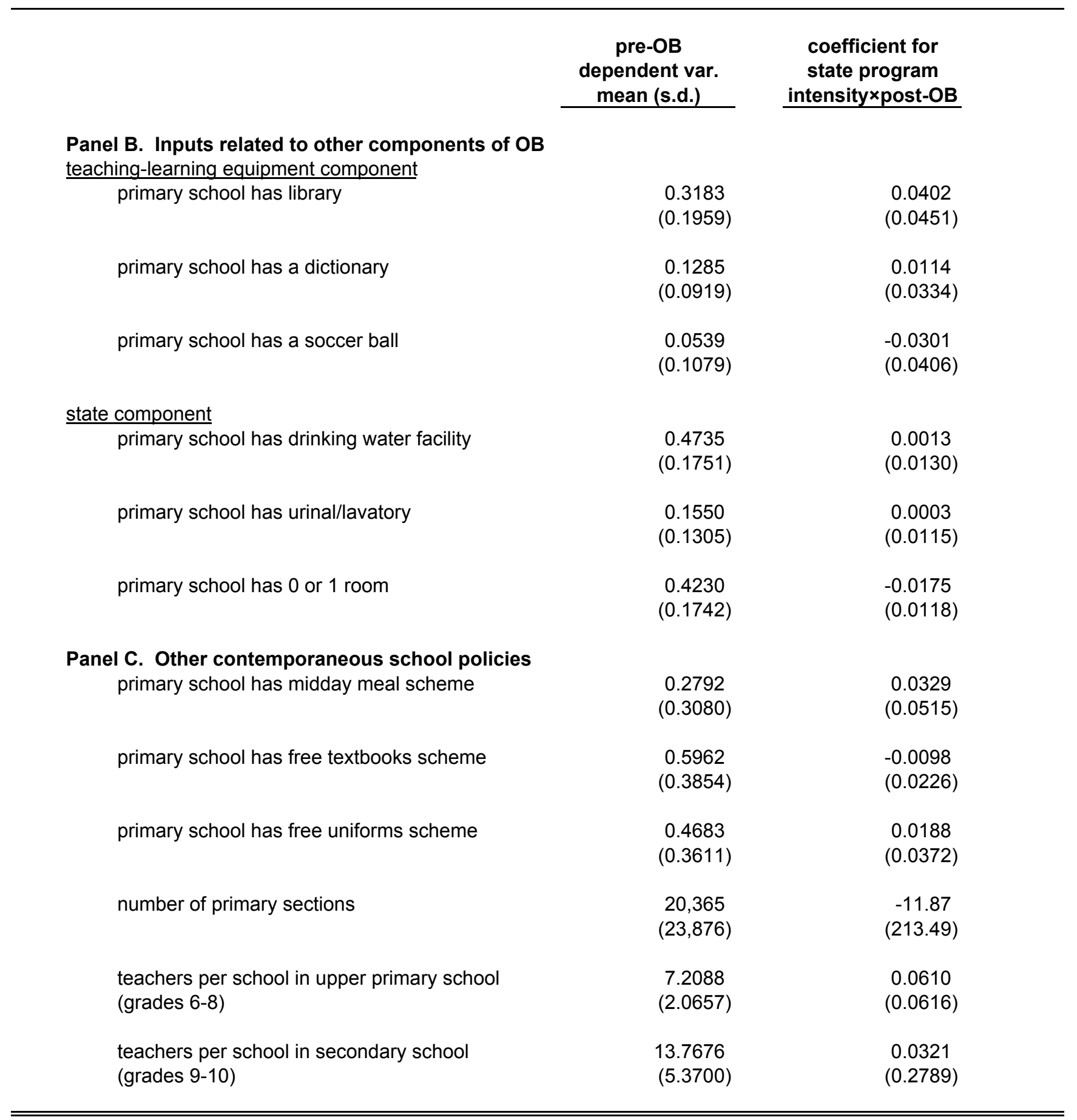

Notes: Data from 1986 and 1993 All-India Educational Survey. Each row is from a separate regression (weighted to obtain population means). Regressions use state-year cells (31 states $\times 2$ years $=62$ cells).

The coefficient reported is for the interaction term, state program intensity $\times$ post-OB. All specifications also include survey year and state fixed effects, which are not reported here. Robust standard errors in parentheses. Single asterisk denotes statistical significance at the $90 \%$ level of confidence, double $95 \%$, triple $99 \%$. 
Table 4. Descriptive Statistics, National Sample Survey Data

Panel A. Girls Aged 12-18

completed primary school

state program intensity

age

year of birth

rural

scheduled tribe

scheduled caste

region: northeast

region: north

region: east

region: central

region: south

region: west

$\mathrm{HH}$ exp. per capita: top quartile

HH exp. per capita: upper middle quartile

$\mathrm{HH}$ exp. per capita: lower middle quartile

HH exp. per capita: bottom quartile

number of observations

Panel B. Boys Aged 12-18

completed primary school

state program intensity

age

year of birth

rural

scheduled tribe

scheduled caste

region: northeast

region: north

region: east

region: central

region: south

region: west

$\mathrm{HH}$ exp. per capita: top quartile

HH exp. per capita: upper middle quartile

$\mathrm{HH}$ exp. per capita: lower middle quartile

$\mathrm{HH}$ exp. per capita: bottom quartile

number of observations
Pre-OB

Born 1968-77

\begin{tabular}{|c|c|c|c|c|c|}
\hline \multicolumn{3}{|c|}{ Born 1968-77 } & \multicolumn{3}{|c|}{ Born 1978-83 } \\
\hline $\begin{array}{c}\text { all } \\
\text { pre-OB }\end{array}$ & $\begin{array}{c}\text { high } \\
\text { intensity } \\
\end{array}$ & $\begin{array}{c}\text { low } \\
\text { intensity }\end{array}$ & $\begin{array}{c}\text { all } \\
\text { post-OB }\end{array}$ & $\begin{array}{c}\text { high } \\
\text { intensity } \\
\end{array}$ & $\begin{array}{c}\text { low } \\
\text { intensity }\end{array}$ \\
\hline 0.46 & 0.45 & 0.47 & 0.58 & 0.59 & 0.56 \\
\hline 1.65 & 2.96 & 0.61 & 1.60 & 2.92 & 0.60 \\
\hline 15.43 & 15.45 & 15.41 & 13.84 & 13.80 & 13.86 \\
\hline 1973 & 1973 & 1973 & 1980 & 1980 & 1980 \\
\hline 0.76 & 0.75 & 0.76 & 0.73 & 0.72 & 0.74 \\
\hline 0.08 & 0.13 & 0.05 & 0.08 & 0.13 & 0.04 \\
\hline 0.17 & 0.14 & 0.19 & 0.19 & 0.15 & 0.22 \\
\hline 0.03 & 0.07 & 0.01 & 0.04 & 0.07 & 0.01 \\
\hline 0.24 & 0.04 & 0.39 & 0.25 & 0.03 & 0.41 \\
\hline 0.21 & 0.10 & 0.30 & 0.21 & 0.09 & 0.29 \\
\hline 0.08 & 0.17 & 0.00 & 0.08 & 0.18 & 0.00 \\
\hline 0.25 & 0.31 & 0.21 & 0.24 & 0.31 & 0.19 \\
\hline 0.19 & 0.31 & 0.09 & 0.19 & 0.32 & 0.09 \\
\hline 0.16 & 0.15 & 0.16 & 0.20 & 0.19 & 0.21 \\
\hline 0.28 & 0.28 & 0.28 & 0.27 & 0.27 & 0.27 \\
\hline 0.30 & 0.30 & 0.30 & 0.28 & 0.30 & 0.27 \\
\hline 0.26 & 0.26 & 0.25 & 0.25 & 0.24 & 0.25 \\
\hline 105,055 & 51,241 & 53,814 & 47,969 & 21,584 & 26,385 \\
\hline 0.64 & 0.64 & 0.65 & 0.69 & 0.71 & 0.68 \\
\hline 1.63 & 2.94 & 0.64 & 1.64 & 2.94 & 0.63 \\
\hline 15.40 & 15.40 & 15.40 & 13.85 & 13.86 & 13.84 \\
\hline 1973 & 1973 & 1973 & 1980 & 1980 & 1980 \\
\hline 0.76 & 0.76 & 0.77 & 0.75 & 0.74 & 0.76 \\
\hline 0.08 & 0.12 & 0.04 & 0.08 & 0.13 & 0.04 \\
\hline 0.18 & 0.14 & 0.20 & 0.20 & 0.15 & 0.23 \\
\hline 0.04 & 0.07 & 0.01 & 0.04 & 0.08 & 0.01 \\
\hline 0.26 & 0.04 & 0.43 & 0.25 & 0.03 & 0.43 \\
\hline 0.22 & 0.09 & 0.31 & 0.21 & 0.09 & 0.32 \\
\hline 0.08 & 0.19 & 0.00 & 0.09 & 0.20 & 0.00 \\
\hline 0.22 & 0.29 & 0.16 & 0.22 & 0.29 & 0.16 \\
\hline 0.19 & 0.33 & 0.09 & 0.19 & 0.32 & 0.08 \\
\hline 0.17 & 0.16 & 0.17 & 0.20 & 0.20 & 0.20 \\
\hline 0.29 & 0.29 & 0.29 & 0.28 & 0.28 & 0.28 \\
\hline 0.30 & 0.30 & 0.30 & 0.28 & 0.28 & 0.28 \\
\hline 0.25 & 0.25 & 0.24 & 0.24 & 0.24 & 0.25 \\
\hline 127,659 & 61,206 & 66,453 & 58,948 & 26,740 & 32,208 \\
\hline
\end{tabular}

Notes: Weighted by NSS weights. Standard deviations in parentheses. Data from NSS Round 42 Schedule 25.2 (1986/87), Round 43 Schedule 10 (1987/88), Round 50 Schedule 10 (1993/94) and Round 52 Schedule 25.2 (1995/96).

Each round-schedule covers a representative sample of Indian households. In different rounds, different schedules are administered. Each schedule has unique supplemental questions; Schedule 25.2 has more questions on participation in education and Schedule 10 has more on employment and unemployment. All the NSS variables used in this paper are available in each round-schedule. 
Table 5. Effect on Primary School Completion for Girls

\begin{tabular}{|c|c|c|c|c|c|c|c|c|c|c|}
\hline & $\begin{array}{c}\begin{array}{c}\text { basic } \\
\text { ctrls }\end{array} \\
(1)\end{array}$ & & 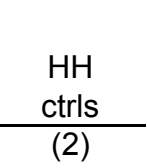 & & $\begin{array}{c}\begin{array}{c}\text { region- } \\
\text { specific } \\
\text { trend }\end{array} \\
(3)\end{array}$ & & $\begin{array}{c}\begin{array}{c}\text { state- } \\
\text { specific } \\
\text { trend }\end{array} \\
(4)\end{array}$ & & $\begin{array}{c}\text { state prog. } \\
\text { intensityx } \\
\text { year of birth }\end{array}$ & \\
\hline $\begin{array}{l}\text { state program } \\
\text { intensity } \times \text { post }-O B\end{array}$ & $\begin{array}{c}0.0161 \\
(0.0029)\end{array}$ & $* * *$ & $\begin{array}{c}0.0165 \\
(0.0026)\end{array}$ & $* * *$ & $\begin{array}{c}0.0120 \\
(0.0028)\end{array}$ & $* * *$ & $\begin{array}{c}0.0093 \\
(0.0044)\end{array}$ & $* *$ & $\begin{array}{c}0.0091 \\
(0.0044)\end{array}$ & $* *$ \\
\hline \multicolumn{11}{|l|}{ Controls for differential trends } \\
\hline Region dummies×YOB & NO & & NO & & YES & & NO & & NO & \\
\hline State dummies $\times$ YOB & NO & & NO & & NO & & YES & & NO & \\
\hline State program intensity $\times Y O B$ & NO & & NO & & NO & & NO & & $\begin{array}{c}0.0010 \\
(0.0005)\end{array}$ & ** \\
\hline rural dummy & -0.2610 & $* * *$ & -0.1519 & $* * *$ & -0.1854 & $* * *$ & -0.1517 & $* * *$ & -0.1519 & $* * *$ \\
\hline \multicolumn{11}{|c|}{ social group: omitted category is not scheduled tribe, not scheduled caste, not missing } \\
\hline scheduled tribe & -0.2159 & *** & -0.0980 & $* * *$ & -0.0982 & $* * *$ & -0.0987 & *** & -0.0981 & $* * *$ \\
\hline scheduled caste & -0.1691 & *** & -0.0685 & $* * *$ & -0.0682 & $* * *$ & -0.0689 & *** & -0.0685 & $* * *$ \\
\hline missing value for social group & -0.2309 & & -0.1996 & * & -0.1853 & & -0.1982 & * & -0.2004 & * \\
\hline \multicolumn{11}{|c|}{ HH per capita expenditure quartile: omitted category is bottom quartile } \\
\hline lower middle quartile & & & 0.0590 & $* * *$ & 0.0581 & $* * *$ & 0.0581 & $* * *$ & 0.0589 & $* * *$ \\
\hline upper middle quartile & & & 0.1272 & *** & 0.1259 & $* * *$ & 0.1260 & $* * *$ & 0.1272 & $* * *$ \\
\hline top quartile & & & 0.1761 & $* * *$ & 0.1749 & $* * *$ & 0.1755 & $* * *$ & 0.1761 & $* * *$ \\
\hline \multicolumn{11}{|c|}{ male adult education: omitted category is illiterate } \\
\hline literate less than primary & & & 0.1302 & $* * *$ & 0.1297 & $* * *$ & 0.1307 & $* * *$ & 0.1303 & $* * *$ \\
\hline literate primary & & & 0.2533 & $* \star *$ & 0.2532 & $* * *$ & 0.2542 & *** & 0.2533 & $* * *$ \\
\hline literate middle school & & & 0.3179 & $* * *$ & 0.3181 & $* * *$ & 0.3187 & $* * *$ & 0.3179 & $* * *$ \\
\hline literate secondary school & & & 0.3655 & *** & 0.3661 & $* * *$ & 0.3657 & $* * *$ & 0.3655 & $* * *$ \\
\hline literate post-secondary & & & 0.3927 & $* * *$ & 0.3935 & $* * *$ & 0.3927 & $* * *$ & 0.3927 & $* * *$ \\
\hline missing value & & & 0.1222 & *** & 0.1232 & *** & 0.1233 & *** & 0.1223 & $* * *$ \\
\hline \multicolumn{11}{|c|}{ female adult education: omitted category is illiterate } \\
\hline literate less than primary & & & 0.1869 & $* * *$ & 0.1868 & $* * *$ & 0.1878 & *** & 0.1869 & $* * *$ \\
\hline literate primary & & & 0.2212 & $* * *$ & 0.2210 & $* * *$ & 0.2211 & *** & 0.2211 & $* * *$ \\
\hline literate middle school & & & 0.1779 & *** & 0.1794 & $\star * \star$ & 0.1796 & $* * *$ & 0.1779 & $* * *$ \\
\hline literate secondary school & & & 0.1284 & *** & 0.1300 & $* * *$ & 0.1291 & $* * *$ & 0.1284 & $* * *$ \\
\hline literate post-secondary & & & 0.0996 & *** & 0.1005 & $* * *$ & 0.1007 & $* * *$ & 0.0997 & $* * *$ \\
\hline missing value & & & 0.0002 & & 0.0002 & & 0.0001 & & 0.0003 & \\
\hline Year of birth dummies & YES & & YES & & YES & & YES & & YES & \\
\hline State of residence dummies & YES & & YES & & YES & & YES & & YES & \\
\hline Survey year dummies & YES & & YES & & YES & & YES & & YES & \\
\hline Subround dummies & YES & & YES & & YES & & YES & & YES & \\
\hline Adjusted R-squared & 0.2190 & & 0.3687 & & 0.3703 & & 0.3703 & & 0.3688 & \\
\hline Number of observations & 153,024 & & 153,024 & & 153,024 & & 153,024 & & 153,024 & \\
\hline
\end{tabular}

Notes: Each column is from estimating a separate linear probability model, weighted by NSS weights. Robust standard errors in parentheses. Single asterisk denotes statistical significance at the $90 \%$ level of confidence, double $95 \%$, triple $99 \%$. Sample is as in Table 4. 
Table 6. Effect on Primary School Completion for Boys

\begin{tabular}{|c|c|c|c|c|c|c|c|c|c|c|}
\hline & $\begin{array}{c}\begin{array}{c}\text { basic } \\
\text { ctrls }\end{array} \\
(1)\end{array}$ & & 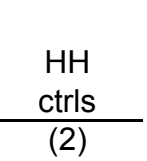 & & $\begin{array}{c}\begin{array}{c}\text { region- } \\
\text { specific } \\
\text { trend }\end{array} \\
(3)\end{array}$ & & $\begin{array}{c}\begin{array}{c}\text { state- } \\
\text { specific } \\
\text { trend }\end{array} \\
(4)\end{array}$ & & $\begin{array}{c}\begin{array}{c}\text { state prog. } \\
\text { intensityx } \\
\text { year of birth }\end{array} \\
(5)\end{array}$ & \\
\hline $\begin{array}{l}\text { state program } \\
\text { intensity×post-OB }\end{array}$ & $\begin{array}{c}0.0164 \\
(0.0028)\end{array}$ & $* * *$ & $\begin{array}{c}0.0144 \\
(0.0026)\end{array}$ & $* * *$ & $\begin{array}{c}0.0100 \\
(0.0027)\end{array}$ & $* * *$ & $\begin{array}{c}0.0034 \\
(0.0045)\end{array}$ & & $\begin{array}{c}0.0027 \\
(0.0045)\end{array}$ & \\
\hline \multicolumn{11}{|l|}{ Controls for differential trends } \\
\hline Region dummies×YOB & NO & & NO & & YES & & NO & & NO & \\
\hline State dummies $\times$ YOB & NO & & NO & & NO & & YES & & NO & \\
\hline State program intensity $\times Y O B$ & NO & & NO & & NO & & NO & & $\begin{array}{c}0.0015 \\
(0.0005)\end{array}$ & $* * *$ \\
\hline rural dummy & -0.1348 & *** & -0.0527 & $* * *$ & -0.0851 & *** & -0.0525 & *** & -0.0528 & *** \\
\hline \multicolumn{11}{|c|}{ social group: omitted category is not scheduled tribe, not scheduled caste, not missing } \\
\hline scheduled tribe & -0.1775 & $* * *$ & -0.0853 & $* * *$ & -0.0850 & $* * *$ & -0.0862 & *** & -0.0854 & *** \\
\hline scheduled caste & -0.1203 & *** & -0.0382 & *** & -0.0384 & *** & -0.0386 & *** & -0.0382 & *** \\
\hline missing value for social group & -0.2180 & & -0.2225 & & -0.2206 & & -0.2126 & & -0.2197 & \\
\hline \multicolumn{11}{|c|}{ HH per capita expenditure quartile: omitted category is bottom quartile } \\
\hline lower middle quartile & & & 0.0631 & $* * *$ & 0.0627 & *** & 0.0626 & *** & 0.0630 & *** \\
\hline upper middle quartile & & & 0.1088 & *** & 0.1081 & *** & 0.1079 & *** & 0.1087 & $* * *$ \\
\hline top quartile & & & 0.1465 & *** & 0.1448 & $* * *$ & 0.1461 & *** & 0.1465 & $* * *$ \\
\hline \multicolumn{11}{|c|}{ male adult education: omitted category is illiterate } \\
\hline literate less than primary & & & 0.1604 & *** & 0.1608 & *** & 0.1609 & *** & 0.1603 & *** \\
\hline literate primary & & & 0.2559 & *** & 0.2564 & *** & 0.2571 & *** & 0.2558 & *** \\
\hline literate middle school & & & 0.3000 & *** & 0.2999 & *** & 0.3007 & *** & 0.3000 & $* * *$ \\
\hline literate secondary school & & & 0.3230 & *** & 0.3235 & $* * *$ & 0.3234 & *** & 0.3231 & *** \\
\hline literate post-secondary & & & 0.3308 & *** & 0.3318 & *** & 0.3321 & *** & 0.3308 & *** \\
\hline missing value & & & 0.1106 & $* * *$ & 0.1114 & $* * *$ & 0.1118 & *** & 0.1107 & *** \\
\hline \multicolumn{11}{|c|}{ female adult education: omitted category is illiterate } \\
\hline literate less than primary & & & 0.0937 & $* * *$ & 0.0941 & $* * *$ & 0.0945 & *** & 0.0935 & $* * *$ \\
\hline literate primary & & & 0.1168 & *** & 0.1178 & *** & 0.1174 & *** & 0.1166 & *** \\
\hline literate middle school & & & 0.0942 & *** & 0.0939 & $* * *$ & 0.0941 & *** & 0.0941 & *** \\
\hline literate secondary school & & & 0.0735 & *** & 0.0758 & $* * *$ & 0.0723 & *** & 0.0733 & *** \\
\hline literate post-secondary & & & 0.0611 & *** & 0.0672 & $* * *$ & 0.0617 & *** & 0.0610 & *** \\
\hline missing value & & & 0.0175 & $* * *$ & 0.0174 & *** & 0.0170 & *** & 0.0175 & *** \\
\hline Year of birth dummies & YES & & YES & & YES & & YES & & YES & \\
\hline State of residence dummies & YES & & YES & & YES & & YES & & YES & \\
\hline Survey year dummies & YES & & YES & & YES & & YES & & YES & \\
\hline Subround dummies & YES & & YES & & YES & & YES & & YES & \\
\hline Adjusted R-squared & 0.1013 & & 0.2065 & & 0.2085 & & 0.2084 & & 0.2066 & \\
\hline Number of observations & 186,607 & & 186,607 & & 186,607 & & 186,607 & & 186,607 & \\
\hline
\end{tabular}

Notes: Each column is from estimating a separate linear probability model, weighted by NSS weights. Robust standard errors in parentheses. Single asterisk denotes statistical significance at the $90 \%$ level of confidence, double $95 \%$, triple $99 \%$. Sample is as in Table 4. 
Table 7. Effect on Primary School Completion by HH Expenditure Quartile

\begin{tabular}{|c|c|c|c|c|c|c|c|}
\hline & $\begin{array}{c}\mathrm{HH} \\
\text { ctrls }\end{array}$ & & $\begin{array}{c}\text { region- } \\
\text { specific } \\
\text { trend } \\
(2)\end{array}$ & & $\begin{array}{c}\text { state- } \\
\text { specific } \\
\text { trend } \\
(3)\end{array}$ & & $\begin{array}{c}\text { state prog. } \\
\text { intensityx } \\
\text { year of birth }\end{array}$ \\
\hline \multicolumn{8}{|l|}{ Panel A. Girls } \\
\hline Treat×Top Quartile & $\begin{array}{c}0.0009 \\
(0.0042)\end{array}$ & & $\begin{array}{l}-0.0029 \\
(0.0043)\end{array}$ & & $\begin{array}{l}-0.0054 \\
(0.0057)\end{array}$ & & $\begin{array}{l}-0.0062 \\
(0.0056)\end{array}$ \\
\hline Treat $\times$ Upper Middle Quartile & $\begin{array}{c}0.0140 \\
(0.0035)\end{array}$ & *** & $\begin{array}{c}0.0101 \\
(0.0037)\end{array}$ & $* * *$ & $\begin{array}{c}0.0076 \\
(0.0050)\end{array}$ & & $\begin{array}{c}0.0069 \\
(0.0050)\end{array}$ \\
\hline Treat×Lower Middle Quartile & $\begin{array}{c}0.0182 \\
(0.0037)\end{array}$ & *** & $\begin{array}{c}0.0137 \\
(0.0038)\end{array}$ & $\star \star \star *$ & $\begin{array}{c}0.0114 \\
(0.0051)\end{array}$ & $* *$ & $\begin{array}{l}0.0112 \\
(0.0051)\end{array}$ \\
\hline Treat×Bottom Quartile & $\begin{array}{c}0.0295 \\
(0.0040)\end{array}$ & *** & $\begin{array}{c}0.0248 \\
(0.0041)\end{array}$ & $\star * \star *$ & $\begin{array}{c}0.0216 \\
(0.0054)\end{array}$ & $\star * *$ & $\begin{array}{l}0.0223 \\
(0.0054)\end{array}$ \\
\hline \multicolumn{8}{|l|}{ Panel B. Boys } \\
\hline Treat×Top Quartile & $\begin{array}{c}0.0042 \\
(0.0040)\end{array}$ & & $\begin{array}{c}0.0002 \\
(0.0041)\end{array}$ & & $\begin{array}{l}-0.0059 \\
(0.0055)\end{array}$ & & $\begin{array}{l}-0.0075 \\
(0.0055)\end{array}$ \\
\hline Treat×Upper Middle Quartile & $\begin{array}{c}0.0110 \\
(0.0033)\end{array}$ & $* * *$ & $\begin{array}{c}0.0069 \\
(0.0034)\end{array}$ & $\star * \star *$ & $\begin{array}{c}0.0004 \\
(0.0050)\end{array}$ & & $\begin{array}{l}-0.0005 \\
(0.0050)\end{array}$ \\
\hline Treat×Lower Middle Quartile & $\begin{array}{c}0.0211 \\
(0.0037)\end{array}$ & *** & $\begin{array}{c}0.0170 \\
(0.0037)\end{array}$ & $\star * \star *$ & $\begin{array}{c}0.0102 \\
(0.0052)\end{array}$ & $* *$ & $\begin{array}{l}0.0095 \\
(0.0052)\end{array}$ \\
\hline Treat×Bottom Quartile & $\begin{array}{c}0.0196 \\
(0.0040)\end{array}$ & $* * *$ & $\begin{array}{c}0.0149 \\
(0.0042)\end{array}$ & $\star * *$ & $\begin{array}{c}0.0070 \\
(0.0056)\end{array}$ & & $\begin{array}{c}0.0078 \\
(0.0055)\end{array}$ \\
\hline
\end{tabular}

Notes: Each cell is from estimating a separate linear probability model, weighted by NSS weights.

Robust standard errors in parentheses. Single asterisk denotes statistical significance at the $90 \%$ level of confidence, double 95\%, triple 99\%. Sample is as in Table 4.

Treat $=$ state program intensity $\times$ post-OB. 